\title{
PROPOSING A NEW MEASURE OF DISTANCE IN THE GRAVITY SETTING: EVIDENCE FROM LATIN AMERICA
}

\author{
Juan Felipe Mejia* \\ Andrés Ramírez Hassan ${ }^{\dagger}$
}

\begin{abstract}
Resumo
O modelo de gravidade é uma ferramenta de trabalho que tem sido amplamente usada no comércio internacional. No entanto, uma questão empírica que surge com frequência está relacionada com a conceptualização e a medição de um índice de distância económica. Na configuração de gravidade padrão, o uso de proxies para os custos do comércio para quantificar e analisar a distância é um método comumente usado. Nós construímos o nosso índice usando Análise de factores Múltiplos. Esta técnica resume, em apenas um factor, informações relacionadas com as variáveis geográficas, culturais, políticas e ecocômicas que possam afetar o comércio internacional entre os países. Estas estimativas indicam que os sinais dos fatores de carga na Análise de factores Múltiplos são intuitivamente plausivel, e exercícios de painel de dados dão resultados sensíveis robustos.
\end{abstract}

Palavras-chave: Modelo equação de gravidade, Análise factorial Múltipla, Painel de dados, Distância do Comércio.

\begin{abstract}
The gravity model is a workhorse tool that has been widely used in international trade. However, one empirical question that frequently arises is related to the conceptualization and measurement of an economic distance index. Our study proposes an index based on Multiple Factor Analysis. This technique summarizes information related to the geographical, cultural, political and economic variables that might affect international trade between countries. Estimates indicate that the signs of the load factors in the Multiple Factor Analysis are intuitively plausible, and panel data exercises give sensible robust outcomes.
\end{abstract}

Keywords: Gravity Equation Model, Multiple Factor Analysis, Panel Data, Trade Distance.

JEL classification: F11, F14

DOI: http://dx.doi.org/10.11606/1413-8050/ea154363

\footnotetext{
${ }^{*}$ Department of Economics, School of Economics and Finance, Universidad EAFIT. Carrera 49 7 Sur - 50 Medellín, Colombia. Phone: +57 42619500 Ext. 9354. Fax: +57 4 2664284. E-mail: jfmejia@eafit.edu.co

${ }^{\dagger}$ Departament of Economics, School of Economics and Finance, Universidad EAFIT. Carrera 49 7 Sur - 50 Medellín, Colombia. Phone: +57 42619500 Ext. 9402. Fax: +57 4 2664284. E-mail: aramir21@eafit.edu.co
} 


\section{Introduction}

The gravity model of international trade is a workhorse tool that has been used in a wide range of empirical fields. It has been stressed that it has provided some of the most robust empirical findings in economics (Leamer \& Levinsohn 1995). Usually, when the gravity equation has been tested, the estimated effects of distance and output have been shown to be economically and statistically significant and reasonably consistent across studies (Rose 2004). In addition, the gravity model has been able to explain most of the variation in international trade (Mejia 2011). Its appropriateness for analysing Foreign Direct Investment flows has also been demonstrated (Walkenhorst 2004). Empirical applications include the relation between trade and migration (Bettin \& Lo Turco 2012), the relation between technological progress and innovation (Uzagalieva et al. 2012), and the impact of time differences between countries on international trade, complementing the effect of geographical distance (Anderson 2013), among other innovative approaches.

Distance, a proxy for trading costs, is expected to negatively affect the flow of international trade between a pair of countries. Some studies based on the gravity model have applied direct measures of transport cost barriers to trade, but the majority of them rely on distance as a proxy for transport costs (Brun et al. 2005) . As noted by Huang (2007), there is, however, no consensus on what geographic distances are proxying for: the costs derived from distance may include varied components, such as freight charges, cultural dissimilarities, and other barriers which can be difficult to measure (Anderson \& Marcouiller 1999). Batra (2004), cited in Correia Leite (2008), argues that distance can also be a proxy for the time elapsed during shipment, synchronization costs, transaction costs, or cultural distance (Mejia 2011). In consequence, while distance has always been an important variable in gravity equations, authors have never been sure exactly what costs distance represents (Baier \& Bergstrand 2001).

From an empirical perspective, three technical problems are present in a significant number of studies. In the first place, many of the variables included in a model representing economic distance are correlated, leading to a loss of precision. In the second place, some of these variables are categorical, which implies that a measure of distance should take this fact into account. And third, some geographical or cultural measures of distance are constant through time, which generates problems in the context of fixed effects panel data models, as being the ones that are required to control for average trade resistance over time, one of the main characteristics of the gravity model.

This paper introduces a measure of economic distance that incorporates geographical, cultural, social, and economic aspects, which is then used in an econometric application of the gravity model for some selected Latin American countries. Our measure offers statistical and economic advantages: an index of economic distance, which includes physical distance as well as other variables in the gravity model, based on Multiple Factor Analysis, takes into consideration that some variables are qualitative whereas others are quantitative. Using the first dimension of the Multiple Factor Analysis as an index of distance improves the precision of the parameter estimates in the econometric exercises, since it mitigates the multicollinearity problem. In addition, our economic distance index varies through time, then we can introduce it in a fixed effects data setting to control for economic distance. In particular, our 
model specification is dynamic, which allows taking into account that the establishment of distribution and service networks between business partners requires time, as well as habit formation among consumers. From a technical perspective, we obtain short and long term elasticities and semi-elasticities associated with the GDP and the economic distance index, respectively.

To test the gravity model, we estimate the effects of the Gross Domestic Product and our distance on exports by using a panel data structure from 1995 to 2010 . The estimations indicate that the signs of the load factors are intuitively plausible, and that the panel data estimations yield sensible robust outcomes.

\section{Distance in the Gravity Setting: An Unresolved Question}

The gravity model has been used in a wide range of empirical fields, some of its applications being the impact of trade agreements, exchange rate volatility, currency unions, foreign direct investment (FDI) between countries, and the so-called border effect (Baldwin \& Taglioni 1999). Other investigations that have been conducted in the light of the gravity model range from the effect of foreign aid on FDI flows, to the effects on trade of democracy, environmental regulations or corruption and insecurity. Three aspects have been crucial for the gravity models recognition: its suitability for explaining international trade flows, the accessibility of the data needed for its estimation, and the respectability of a number of seminal papers that have established the gravity models reputation and proposed a set of standard practices that are used to address different empirical questions.

One of the most influential empirical papers dealing with the gravity equation, Rose (2000), notes that the gravity model of international trade has a remarkably consistent history of success as an empirical tool. He also cites Leamer \& Levinsohn (1995), who describe the gravity model as having provided some of the clearest and most robust empirical findings in economics. Influential empirical studies dealing with the gravity equation include Anderson (2013), Feenstra et al. (2001), Evenett \& Keller (2002), Eaton \& Kortum (2002), Rose $(2000,2004)$, Soloaga \& Winters (2001), and Subramanian \& Wei (2007), among others. As stated by Head \& Mayer (2014), one crucial empirical relation included in gravity equations is the strong negative relation between physical distance and trade.

Despite its empirical success, the conceptualization and measurement of distance in the gravity setting remains an unresolved question. As stated by Disdier \& Head (2008), the answers to many relevant economic questions largely depend on how much distance affects trade. The so-called distance puzzle has been frequently addressed in the literature, where the vast majority of studies have found a negative effect of distance on trade that persists in a very wide range of estimations. Furthermore, these distance effects are not decreasing over time (Disdier \& Head 2008). Efforts have been undertaken to improve measures of bilateral distance. But, as mentioned previously, there is no consensus about what distance is proxying for, and the concept is still not well defined (Baldwin \& Taglioni 1999).

Taking these considerations into account, we propose a one-variable index of economic distance where some categorical variables are considered. Therefore, our main contribution is related to the improvement of the precision of 
the parameter estimates in econometric exercises and propose a distance index that varies through time. Thus, we attempt to implement an index that allows estimation of fixed effects panel data models, and mitigate the multicollinearity problem.

\section{Empirical Strategy and Results}

We analyse the period 1995-2010, due to the availability of information and more specifically because the democracy index measured by Polity 2 from the Polity IV data is only available from 1995 onwards. This variable measures the level of democracy of a country based on an evaluation of the competitiveness and openness of its elections, the nature of political participation in general, and the extent of checks on executive authority. It ranges from -10 (total autocracy) to 10 (perfect democracy). Several previous works have used the Polity IV data set, for instance: Swamy et al. (2001) and Gatti (2004). In addition, as the basic gravity theory is a modified expenditure function which explains unidirectional international trade from an origin country to many destination trade partners (Baldwin \& Taglioni 2006) ${ }^{1}$, we have as dependent variable exports from five South American countries and five Central American countries, namely: Argentina, Brazil, Chile, Colombia, Ecuador, El Salvador, Guatemala, Honduras, Mexico, and Panama, to their trade partners. Thus we present results for ten different countries. Table A.1 shows the list of variables, their definitions, and sources.

Also, it should be noted that our strategy also avoids the assumption of symmetric international trade barriers (Helpman et al. 2008, Disdier \& Head 2008), an assumption that is implicit in empirical research that involves simultaneously many countries where bilateral trade, measured as the average of exports and imports, is the dependent variable. In addition, we must recognize that our measure of trade flow does not take into consideration zero trade flows across pairs of countries; this means that there is a selection bias, but, as Helpman et al. (2008) established, this selection bias is not as important as it seems at first glance. However, we should consider this point in our specific application in future research.

We can find descriptive statistics in Table A.2. When building the dataset, each country's export basket contained at least $70 \%$ of its exports. When analysing the descriptive statistics, it is interesting to notice how the coverage for Chilean exports is $70.48 \%$, while in the Mexican case, it goes up to $97.62 \%$. In our dataset, Honduras is the country with the fewest trade partners (32), but $85.23 \%$ of its exports are represented. Mexico is the country with the highest level of exports, and Brazil is the country with the highest Gross Domestic Product in our dataset. Additionally, El Salvador is the country whose trade partners have the highest average GDPs, but also the highest volatilities. Concerning the democracy index, it can be observed that countries like Chile and Panama obtain the maximum score (9), while Ecuador gets the minimum score (6.68).

To create our economic distance index, we consider variables that have been extensively used in the gravity equation setting. We use three categorical variables: the existence of a common border (Feenstra et al. 2001, Anderson \&

\footnotetext{
${ }^{1}$ Most of the applied research regarding the gravity equation omits this fact, which is called the silver medal mistake by Baldwin \& Taglioni (2006).
} 
van Wincoop 2003, Rose 2004), sharing of a common language, and having a trading partner that is an island (Limáo \& Venables 2013, Glick \& Rose 2002, Rose 2004), and three quantitative variables: the geographical distance measured in kilometers between the capital cities (Limáo \& Venables 2013, Anderson \& van Wincoop 2003), the bilateral real exchange rate between trade partners (Rose 2000, Micco et al. 2003, Belke \& Spies 2008), and the absolute difference in the democracy index between trade partners (Kucera \& Sarna 2006, Yu 2010). This last variable is introduced to capture political differences between trade partners. As can be seen from the previous references, these variables have been extensively used in the gravity equation setting.

Traditionally, the effect of distance is interpreted as a proxy for transport costs, an indicator of time elapsed during shipment, synchronization costs, transaction costs or cultural distance (Correia Leite 2008). Therefore, we try to capture geographical, economic, cultural, and political aspects between the origin country and its trade partners to build our index.

We use the first dimension associated with the previous variables from a Multiple Factor Analysis to calculate our economic distance index. This multivariate statistical technique is a multiple factor method to explore data with numerical and categorical variables, which can be considered a mix between Principal Component Analysis and Multiple Correspondence Analysis, which ensures balancing the influence of both types of data (Escofier \& Pagès 1994, Pagès 2004, Bécue-Bertaut \& Pagès 2008). The main idea of this technique is to find common structures present in different sets of variables.

Let I denote a set of countries described by two sets of variables, quantitative $\left(x_{i k}\right)$ and categorical $\left(z_{i k}\right)$, where each set is composed of three variables. Specifically, the first set contains the distance, the bilateral exchange rate, and the absolute difference in the democracy index, and the second group is composed of the existence of a common border, sharing a common language, and having a trading partner that is an island. To balance the influence of these sets, the Multiple Factor Analysis follows a geometric approach where the inertia of each set of variables is standardized using the first principal axis, that is, the weight of the columns belonging to each set is divided by the first eigenvalue of the separate analysis of each set.

To integrate the categorical set into the Multiple Factor Analysis, it is necessary to use the equivalence between a Multiple Correspondence Analysis and a non-standardized weighted Principal Components Analysis. Given $\left(z_{i k}-w_{k}\right) / w_{k}$, where $z_{i k}=1$ if $i$ belongs to the category $k$ and 0 if it does not, $w_{k}=\sum_{i \in I} z_{i k} / I$, and $Q=\sum_{k=1}^{3} w_{k}$, then the distances between countries and variables induced by this Principal Component Analysis are equal to the distances usually considered in Multiple Correspondence Analysis. Specifically, the distance between countries $i$ and $l$ is

$$
d^{2}(i, l)=\sum_{k=1}^{3} \frac{1}{Q w_{k}}\left(z_{i k}-z_{l k}\right)^{2}
$$

Therefore, the Multiple Factor Analysis solves different problems related to statistical factor analysis: first of all, this technique avoids the possibility of a single group having a dominant influence in the first factor. Second, it allows simultaneous analysis of numerical and categorical variables. Third, MFA solves the representation problem using weights that balance the inertia between different groups of variables. Fourth, it allows finding factors that 
are common to several groups of variables in a more stable way. And finally, it permits a global representation of groups (Escofier \& Pagès 1994).

The outcomes of our Multiple Factor Analysis can be observed in Table 1. Regarding the numerical variables, a greater distance, larger differences in the real exchange rate, and greater political discrepancies imply a larger economic distance index. Concerning the categorical variables, our analysis shows that sharing a border and sharing a common language imply less distance, while having an island as a trade partner implies a larger economic distance ${ }^{2}$.

One of the most relevant characteristics of Multiple Factor Analysis is that one can obtain different load factors for each categorical variable. For instance, as can be observed in Table 1, there are asymmetric effects of these variables on our economic distance index. In particular, sharing a land border has a higher effect in absolute value on economic distance than not sharing a land border. The same pattern can be seen when two partners share a common language. To have an island as a trade partner implies a higher effect on distance than the opposite situation.

In addition, we can estimate the percentage contribution of each variable to our economic distance index. Although there is some heterogeneity between countries, we can see some common patterns. For instance, physical distance is the variable that has the highest contribution to the index, followed by having a common language and sharing a border. On the other hand, the variables that contribute the least to the economic distance index are the real exchange rate and trading with countries that are not islands. We observe that quantitative variables contribute over $47 \%$ on average, while the weight of the categorical variables is approximately $53 \%$.

Taking into consideration that just two variables in our economic distance index can change, namely, the real exchange rate and the absolute difference in political regimes, our outcomes imply that Ceteris Paribus the change from 6 to 2 of the absolute difference in the Polity 2 index between Colombia and Peru in 2000 -due to Peru becoming a more democratic regime in 2000, which meant that its Polity 2 index changed from 1 to 9 - implied a decrease by 1 in the economic distance index between Colombia and Peru, from -1.1 to -2.1. This change should have implications on trade between these countries as will be discussed later.

We can observe in Tables A.3 and A.4 in the Appendix the average economic distance index for each country in our sample. For instance in the case of Colombia, we find in Table A.3 that Ecuador and Venezuela have the lowest economic distance indices, whereas the United Kingdom and Cyprus have the highest indices. Regarding Central America, we show in Table A.4 that El Salvador has the lowest economic distance index in the cases of Guatemala and Honduras, while Singapore has the highest index for El Salvador, Guatemala and Mexico.

In addition, we carried out some principal component analyses for each country with the same numerical variables, and treated the categorical variables as dummy variables equal to 1 if the condition is met, and zero otherwise. The main idea of these exercises was to perform some robustness checks for our results. As can be seen in Table A.5 in the Appendix, we obtained the same intuitive outcomes. Specifically, a larger physical distance, a higher exchange

\footnotetext{
${ }^{2}$ We performed our Multiple Factor Analysis in the R software package (R Development Core Team, 2013). Specifically, we used the library FactoMimeR (Husson et al. 2013).
} 
Table 1: Multiple Factor Analysis: An Economic Distance Index ${ }^{a}$

\begin{tabular}{|c|c|c|c|c|c|c|c|c|c|c|}
\hline Continuous Variables & Argentine & Brazil & Chile & Colombia & Ecuador & EL Salvador & Guatemala & Honduras & Mexico & Panama \\
\hline Distance & $\begin{array}{c}0,9244 \\
(37,88 \%)\end{array}$ & $\begin{array}{c}0,9050 \\
(40,92 \%)\end{array}$ & $\begin{array}{c}0,9219 \\
(39,04 \%)\end{array}$ & $\begin{array}{c}0,8535 \\
(25,75 \%)\end{array}$ & $\begin{array}{c}0,9242 \\
(37,29 \%)\end{array}$ & $\begin{array}{c}0,8817 \\
(31,84 \%)\end{array}$ & $\begin{array}{c}0,8710 \\
(31,59 \%)\end{array}$ & $\begin{array}{l}0,8457 \\
(31,17 \%)\end{array}$ & $\begin{array}{c}0,8755 \\
(33,21 \%)\end{array}$ & $\begin{array}{c}0,8484 \\
(34,69 \%)\end{array}$ \\
\hline Real Exchange Rate & $\begin{array}{l}0,1923 \\
(1,63 \%)\end{array}$ & $\begin{array}{l}0,1166 \\
(0,68 \%)\end{array}$ & $\begin{array}{l}0,1822 \\
(1,52 \%)\end{array}$ & $\begin{array}{c}0,5640 \\
(11,24 \%)\end{array}$ & $\begin{array}{l}0,0746 \\
(0,24 \%)\end{array}$ & $\begin{array}{l}0,1890 \\
(1,46 \%)\end{array}$ & $\begin{array}{l}0,2823 \\
(3,32 \%)\end{array}$ & $\begin{array}{l}0,2834 \\
(3,50 \%)\end{array}$ & $\begin{array}{l}0,2771 \\
(3,32 \%)\end{array}$ & $\begin{array}{l}0,3915 \\
(7,38 \%)\end{array}$ \\
\hline Political Difference & $\begin{array}{l}0,4043 \\
(7,25 \%)\end{array}$ & $\begin{array}{l}0,3398 \\
(5,83 \%)\end{array}$ & $\begin{array}{l}0,3353 \\
(5,16 \%)\end{array}$ & $\begin{array}{c}0,6083 \\
(13,08 \%)\end{array}$ & $\begin{array}{c}0,4915 \\
(10,54 \%)\end{array}$ & $\begin{array}{c}0,6267 \\
(16,08 \%)\end{array}$ & $\begin{array}{c}0,5275 \\
(11,59 \%)\end{array}$ & $\begin{array}{c}0,5640 \\
(13,86 \%)\end{array}$ & $\begin{array}{c}0,5140 \\
(11,44 \%)\end{array}$ & $\begin{array}{l}0,1580 \\
(1,20 \%)\end{array}$ \\
\hline \multicolumn{11}{|l|}{ Categorical Variables } \\
\hline Border NO & $\begin{array}{l}0,4125 \\
(3,10 \%)\end{array}$ & $\begin{array}{l}0,4384 \\
(5,58 \%)\end{array}$ & $\begin{array}{l}0,2164 \\
(1,04 \%)\end{array}$ & $\begin{array}{l}0,2869 \\
(1,67 \%)\end{array}$ & $\begin{array}{l}0,1451 \\
(0,51 \%)\end{array}$ & $\begin{array}{l}0,1764 \\
(0,71 \%)\end{array}$ & $\begin{array}{l}0,2510 \\
(1,43 \%)\end{array}$ & $\begin{array}{l}0,2006 \\
(0,97 \%)\end{array}$ & $\begin{array}{l}0,1118 \\
(0,34 \%)\end{array}$ & $\begin{array}{l}0,1759 \\
(0,73 \%)\end{array}$ \\
\hline Border YES & $\begin{array}{c}-2,5578 \\
(19,24 \%)\end{array}$ & $\begin{array}{c}-2,4116 \\
(30,73 \%)\end{array}$ & $\begin{array}{c}-2,9586 \\
(14,31 \%)\end{array}$ & $\begin{array}{c}-1,8363 \\
(10,74 \%)\end{array}$ & $\begin{array}{c}-2,5395 \\
(8,99 \%)\end{array}$ & $\begin{array}{c}-2,8232 \\
(11,47 \%)\end{array}$ & $\begin{array}{c}-2,7612 \\
(15,83 \%)\end{array}$ & $\begin{array}{c}-3,0090 \\
(14,68 \%)\end{array}$ & $\begin{array}{c}-2,0684 \\
(6,30 \%)\end{array}$ & $\begin{array}{r}-2,7267 \\
(11,37 \%)\end{array}$ \\
\hline Island NO & $\begin{array}{c}-0,2074 \\
(0,78 \%)\end{array}$ & $\begin{array}{c}-0,2615 \\
(2,05 \%)\end{array}$ & $\begin{array}{c}-0,2545 \\
(1,30 \%)\end{array}$ & $\begin{array}{c}-0,2000 \\
(0,84 \%)\end{array}$ & $\begin{array}{c}-0,2641 \\
(1,55 \%)\end{array}$ & $\begin{array}{c}-0,2571 \\
(1,42 \%)\end{array}$ & $\begin{array}{c}-0,1911 \\
(0,80 \%)\end{array}$ & $\begin{array}{c}-0,1964 \\
(0,84 \%)\end{array}$ & $\begin{array}{c}-0,2649 \\
(1,75 \%)\end{array}$ & $\begin{array}{c}-0,3159 \\
(2,13 \%)\end{array}$ \\
\hline Island YES & $\begin{array}{l}1,2863 \\
(4,87 \%)\end{array}$ & $\begin{array}{l}1,7786 \\
13,93 \%)\end{array}$ & $\begin{array}{l}1,3453 \\
(6,90 \%)\end{array}$ & $\begin{array}{l}1,6506 \\
(6,94 \%)\end{array}$ & $\begin{array}{l}1,6903 \\
(9,96 \%)\end{array}$ & $\begin{array}{l}1,9283 \\
10,70 \%)\end{array}$ & $\begin{array}{l}1,5289 \\
(6,47 \%)\end{array}$ & $\begin{array}{l}1,0608 \\
(4,56 \%)\end{array}$ & $\begin{array}{l}1,8019 \\
11,96 \%)\end{array}$ & $\begin{array}{l}1,7695 \\
11,97 \%)\end{array}$ \\
\hline Common Language NO & $\begin{array}{l}0,0138 \\
(7,00 \%)\end{array}$ & $\begin{array}{l}0,0160 \\
(0,01 \%)\end{array}$ & $\begin{array}{l}0,7326 \\
(9,06 \%)\end{array}$ & $\begin{array}{c}0,8259 \\
(10,43 \%)\end{array}$ & $\begin{array}{c}0,8053 \\
(10,85 \%)\end{array}$ & $\begin{array}{l}0,7164 \\
(8,49 \%)\end{array}$ & $\begin{array}{l}0,7620 \\
(9,64 \%)\end{array}$ & $\begin{array}{l}0,7295 \\
(9,49 \%)\end{array}$ & $\begin{array}{c}0,7420 \\
(10,54 \%)\end{array}$ & $\begin{array}{c}0,8305 \\
(11,08 \%)\end{array}$ \\
\hline Common Language YES & $\begin{array}{c}-1,7596 \\
(18,21 \%)\end{array}$ & $\begin{array}{c}-0,5262 \\
(0,24 \%)\end{array}$ & $\begin{array}{c}-1,7469 \\
(21,62 \%)\end{array}$ & $\begin{array}{c}-1,5248 \\
(19,26 \%)\end{array}$ & $\begin{array}{r}-1,4867 \\
(20,03 \%)\end{array}$ & $\begin{array}{c}-1,4981 \\
(17,77 \%)\end{array}$ & $\begin{array}{c}-1,5240 \\
(19,29 \%)\end{array}$ & $\begin{array}{l}-1,6050 \\
(20,89 \%)\end{array}$ & $\begin{array}{c}-1,4840 \\
(21,09 \%)\end{array}$ & $\begin{array}{c}-1,4535 \\
(19,39 \%)\end{array}$ \\
\hline Proportion $^{b}$ & $41,34 \%$ & $31,80 \%$ & $39,16 \%$ & $44,61 \%$ & $39,06 \%$ & $40,88 \%$ & $40,74 \%$ & $39,37 \%$ & $37,02 \%$ & $37,47 \%$ \\
\hline
\end{tabular}

${ }^{a}$ Percentage contribution in parenthesis.

${ }^{b}$ Proportion of the variance explained by the first dimension.

Source: Author's estimations. 
rate, larger political discrepancies, not sharing a land border or language, and having an island as a trade partner, imply a larger distance ${ }^{3}$. Once we built an index of economic distance, we used the product of the Gross Domestic Products as a proxy of the mass between a host country and its trade partners. As the gravity theory is an expenditure function, rather than a demand function, we used the product of the GDPs in current US\$, thus avoiding what Baldwin \& Taglioni (2006) called the bronze medal mistake in the gravity theory.

In addition, we estimated dynamic panel models, because ignoring the dynamics might lead to incorrect inference: this aspect is an important issue in international trade since the establishment of distribution and service networks between business partners implies lower barriers and sunk costs. In addition, there is habit formation among consumers that favors inertial demand (Bun \& Klaassen 2002). Thus, the main estimation framework is based on the dynamic panel data model proposed by Blundell \& Bond (1998). This methodology implements some moment conditions that yield a more efficient estimation (Cameron \& Trivedi 2005) ${ }^{4}$. We should mention that most of the applied research using the gravity equation is based on cross section datasets or static panel models, which means a lack of the dynamic component, which generates bias and inconsistent parameter estimates.

Finally, we should bear in mind that the dynamic panel data estimator is a first difference estimator that controls using fixed effects that are correlated with the stochastic component of the equation. Thus, we take into consideration that the constant term in the physical gravity equation is not constant in the international trade version, and as we do not observe that component, we should control for it through fixed effects, avoiding what Baldwin \& Taglioni (2006) called the gold medal mistake in the gravity model. We must note that most of the literature in the context of panel data models avoids this situation by using pair dummies, that is, a dummy that is 1 for all observations of trade between a given pair of nations (Stack 2009). However, we estimate the unidirectional trade flow between a host country and its trade partners, so we do not have that data structure; hence individual fixed effects are enough to control for the effects of unobserved price indices or the omission of time invariant bilateral variables such as historical, cultural and ethnic factors, whereas our economic distance index controls using border trade, cultural ties, trade restrictions, political differences, and geographical aspects. We estimate the following equation:

$$
\ln \operatorname{Exp}_{i j, t}=\beta_{0}+\beta_{1} \ln E x p_{i j, t-1}+\beta_{2} \ln G D P_{i j, t}+\beta_{3} E c D i s t_{i j, t}+\mu_{i j, t}
$$

where, $\ln \operatorname{Exp}_{i j, t}$ is the level of exports from the host country $i$ to its partner countries $j$ in year $t$.

$\ln G D P_{i j, t}$ is the product of the GDPs of the host country $i$ and its partner countries $j$ in year $t$.

$E c D i s t_{i j, t}$ is our economic distance index between the host country $i$ and its partner countries $j$ in year $t$.

$\mu_{i j, t}$ is a stochastic perturbation for each equation $i$.

\footnotetext{
${ }^{3}$ We performed the Bartlett test of sphericity, and there is no statistical evidence to reject the null hypothesis that these variables are not intercorrelated.

${ }^{4}$ All our panel data models were run on Stata 12.0 (StataCorp 2011).
} 
We tested for the presence of panel unit roots, and this hypothesis is rejected, as well as autocorrelation of order two. Additionally, overidentification restrictions are valid for each model. Finally, all our variables are statistically significant at the $5 \%$ level (see Table 2 ).

As can be observed in Table 2, a higher level of our economic distance index implies a reduction in the level of exports from the host country to its partner countries. In particular, we can see short term semi-elasticities that range between -0.24 for Colombia and -3.32 for Panama, whereas long term semi-elasticities, i.e., $\beta_{3} /\left(1-\beta_{1}\right)$, fluctuate between -0.35 for Chile and -4.00 for Panama. These outcomes imply that an increase by 0.1 in the economic distance index of Colombia, for instance a movement from Panama (-1.90) to Peru (-1.80) (see Table A.3 in the Appendix), generates on average an exports decrease of $2.4 \%$ in the short term, but a decrease of $3.7 \%$ in the long term (see Table 2). Additionally, the short term GDP elasticity is positive and ranges between 0.22 for Brazil to 1.17 for El Salvador. Regarding the long term GDP elasticity, i.e., $\beta_{2} /\left(1-\beta_{1}\right)$, this fluctuates between 0.70 for Guatemala and 1.60 for Ecuador.

We estimated different models in order to perform some robustness checks related to the panel data specification, their assumptions about the stochastic perturbations, and the multivariate statistical technique used to calculate our measure of economic distance. First, we estimated all our dynamic models using a measure of economic distance obtained by Principal Component Analysis, and as can be seen in Table A.6 in the Appendix, we obtain similar outcomes. Additionally, we used the economic distance based on the Multiple Factor Analysis to estimate the gravity equation using Pooled Ordinary Least Squared, Feasible Generalized Least Squared, PraisWinsten, Random Effects, and Instrumental Variables estimators. In particular, the Pooled OLS estimator does not take into account the panel data structure, while the Feasible Generalized Least Squares takes into consideration this fact and controls for possible autocorrelation processes in stochastic errors. In addition, PraisWinsten estimation is a panel data estimator that simultaneously takes into account an autoregressive process and heteroscedasticity in errors. Random Effect estimation assumes that the unobserved heterogeneity is not correlated with the regressors, whereas the Instrumental Variables estimator considers possible contemporaneous endogeneity problems between exports and product of GDPs, so we take as instruments the lags of the latter variable.

As depicted in Tables A.7 and A.8 in the Appendix, the results are robust to the static specification, as well as the assumptions on the stochastic errors. Finally, we used our index of economic distance based on Principal Components Analysis to estimate the gravity equation using the above methods. We can observe in Tables A.9 and A.10 that our outcomes are robust to the multivariate statistical method used to calculate the economic distance.

\section{Conclusions}

The empirical success of the gravity model is explained by different factors. Its theoretical underpinning, wide range of fields of application, the accessibility of the data needed for its estimation, and the respectability of a number of seminal papers that have established the gravity models reputation, have been decisive. 


\begin{tabular}{|c|c|c|c|c|c|c|c|c|c|c|}
\hline Variable & Argentine & Brazil & Chile & Colombia & Ecuador & EL Salvador & Guatemala & Honduras & Mexico & Panama \\
\hline EcDistit & $\begin{array}{c}-0,7064 \\
(0,0230)\end{array}$ & $\begin{array}{c}-0,2616 \\
(0,0208)\end{array}$ & $\begin{array}{c}-0,3452 \\
(0,0152)\end{array}$ & $\begin{array}{c}-0,2472 \\
(0,0204)\end{array}$ & $\begin{array}{c}-1,5057 \\
(0,0429)\end{array}$ & $\begin{array}{c}-1,0140 \\
(0,0962)\end{array}$ & $\begin{array}{c}-0,3897 \\
(0,0347)\end{array}$ & $\begin{array}{c}-1,2050 \\
(0,0862)\end{array}$ & $\begin{array}{c}-0,1915 \\
(0,0218)\end{array}$ & $\begin{array}{c}-3,3197 \\
(0,0993)\end{array}$ \\
\hline $\ln G D P_{i t}$ & $\begin{array}{l}0,2721 \\
(0,0069)\end{array}$ & $\begin{array}{l}0,2263 \\
(0,0113)\end{array}$ & $\begin{array}{l}0,8514 \\
(0,0096)\end{array}$ & $\begin{array}{l}0,4997 \\
(0,0057)\end{array}$ & $\begin{array}{l}0,6512 \\
(0,0153)\end{array}$ & $\begin{array}{l}1,1793 \\
(0,0516)\end{array}$ & $\begin{array}{l}0,4662 \\
(0,0181)\end{array}$ & $\begin{array}{l}0,9821 \\
(0,0206)\end{array}$ & $\begin{array}{l}0,4369 \\
(0,0059)\end{array}$ & $\begin{array}{l}0,7783 \\
(0,0449)\end{array}$ \\
\hline $\ln \operatorname{Exp}_{i t-1}$ & $\begin{array}{l}0,6997 \\
(0,0144)\end{array}$ & $\begin{array}{l}0,7131 \\
(0,0151)\end{array}$ & $\begin{array}{l}0,0129 \\
(0,0015)\end{array}$ & $\begin{array}{l}0,3307 \\
(0,0077)\end{array}$ & $\begin{array}{l}0,5936 \\
(0,0012)\end{array}$ & $\begin{array}{l}0,1346 \\
(0,0066)\end{array}$ & $\begin{array}{l}0,3420 \\
(0,0097)\end{array}$ & $\begin{array}{l}0,0601 \\
(0,0048)\end{array}$ & $\begin{array}{l}0,5051 \\
(0,0075)\end{array}$ & $\begin{array}{l}0,1701 \\
(0,0079)\end{array}$ \\
\hline Constant & $\begin{array}{l}-8,2684 \\
(0,3213)\end{array}$ & $\begin{array}{c}-6,1960 \\
(0,3071)\end{array}$ & $\begin{array}{c}-24,9836 \\
(0,4782)\end{array}$ & $\begin{array}{c}-13,5241 \\
(0,2570)\end{array}$ & $\begin{array}{c}-25,8109 \\
(0,7350)\end{array}$ & $\begin{array}{l}-45,8623 \\
(2,7437)\end{array}$ & $\begin{array}{c}-12,4084 \\
(0,8389)\end{array}$ & $\begin{array}{c}-34,9532 \\
(1,0430)\end{array}$ & $\begin{array}{c}-13,5999 \\
(0,2406)\end{array}$ & $\begin{array}{c}-26,8434 \\
(2,2429)\end{array}$ \\
\hline $\begin{array}{l}\text { Long Term Economic Distance } \\
\text { Semi-elasticity }\end{array}$ & $-2,3526$ & $-0,9118$ & $-0,3497$ & $-0,3693$ & $-3,7050$ & $-1,1717$ & $-0,5922$ & $-1,2821$ & $-0,3869$ & $-4,0001$ \\
\hline Long Term GDP Elasticity & 0,9061 & 0,7888 & 0,8625 & 0,7466 & 1,6024 & 1,3627 & 0,7085 & 1,0449 & 0,8828 & 0,9378 \\
\hline Autocorrelation Test ${ }^{a}$ & $-1.0073+$ & $-1.6868+$ & $0.4083+$ & $0.1791+$ & $1.3157+$ & $-0.4580+$ & $1.5740+$ & $1.4487+$ & $0.0846+$ & $0.6738+$ \\
\hline OIR Test ${ }^{b}$ & $35.2578+$ & $38.2503+$ & $43.4051+$ & $35.3016+$ & $36.6280+$ & $33.1575+$ & $35.5747+$ & $31.3575+$ & $38.3757+$ & $29.1993+$ \\
\hline PUR Test ${ }^{c}$ & $-11.4508-$ & $-1.4259-$ & $-12.2991-$ & $-9.9089-$ & $-5.9416-$ & $-14.482-$ & $-4.4724-$ & $-3.1642-$ & $-3.6359-$ & $-8.2050-$ \\
\hline
\end{tabular}

Standard deviations in parentheses. All variables are statistically significant at $5 \%$

${ }^{a}$ Arellano-Bond autocorrelation test. Null hypothesis: No autocorrelation of order 2.

${ }^{b}$ Sargent test of Over Identification Restrictions. Null hypothesis: Overidentifying restrictions are valid.

${ }^{c}$ Harris and Tzavalis (1999) Pane Unit Root test applied to $\ln E x p_{i t}$. Null hypothesis: panel unit root.

${ }^{+}$No rejection of the null hypothesis.

Rejection of the null hypothesis.

Source: Authors' estimations. 
However, a persistent problem in the literature related to the gravity model of international trade is associated with the conceptualization and measurement of distance. Even though some studies have applied direct measures of transport cost barriers to trade, the majority of them rely on distance as a proxy for transport costs. In addition, there is no consensus on the extent of the distance concept. Certainly, geographical distance and transport costs are relevant. But besides that, synchronization costs, transaction costs, or cultural distance should also be considered.

Taking this limitation into account, the main contribution of this paper is to propose an economic distance index based on geographical, economic, cultural and political aspects, applying it to test the gravity model in 10 Latin American economies using a dynamic specification that allows us to calculate short and long term partial effects controlling for unobserved heterogeneity correlated with the regressors. In our analysis, the gravity equation fits the data well. A higher level in our index of economic distance implies a reduction in trade flows between the trade partners, whereas an increase in GDPs implies exports increase.

This economic distance index is built using Multiple Factor Analysis, which is a multivariate statistical technique that simultaneously incorporates numerical and categorical variables. Our econometric exercises suggest that the outcomes are sensible. These results were also tested using Principal Component Analysis, and basically the same results were obtained.

We must mention that in this paper our focus is on the intensive margin, that is, the trade volume. However, an important issue in international trade is the extensive margin measured, most of the time, through the number of firms that export. Omitting this component might generate biased and inconsistent parameters estimates, as has been established by Helpman et al. (2008).

Unfortunately, an econometric exercise that tackles this issue requires a detailed dataset that was not available, as far as we know, for our sample of Latin American countries. In addition, if there is heteroscedasticity in the stochastic errors, Jensens inequality implies that the parameter estimates in a log-log models can be biased. Thus, Silva \& Tenreyro (2006) propose using Poisson pseudo maximum likelihood estimation to avoid this problem in the context of cross section datasets. However, the statistical arguments that generate this suggestion, as far as we know, are not well developed in the panel data context, and even less in dynamic models like the ones that are estimated in this paper. As a consequence, we have not tried to implement this approach, and suggest it as a possible extension for future research.

\section{Bibliography}

Anderson, E. (2013), 'Time differences, communication and trade: Longitude matters II', Review of World Economics 150, 337-369.

Anderson, J. E. \& van Wincoop, E. (2003), 'Gravity with gravitas: A solution to the border puzzle', American Economic Review 93(1), 170-192.

Anderson, J. \& Marcouiller, D. (1999), Trade, location and security: An empirical investigation, Working Paper 7000, NBER. 
Baier, S. \& Bergstrand, J. (2001), 'The growth of world trade: Tariffs, transport costs, and income similarity', Journal of International Economics 53, 1-27.

Baldwin, R. \& Taglioni, D. (1999), 'Gravity for dummies and dummies for gravity equations', NBER Working Paper Series (Working Paper 12516), 1-31.

Baldwin, R. \& Taglioni, D. (2006), Gravity for dummies and dummies for gravity equations, Working Paper 12516, National Bureau of Economic Research, Cambridge Massachusetts.

Batra, A. (2004), India's global trade potential: The gravity model approach, Working Paper 151, Indian Council for Research on International Economic Relations.

Bécue-Bertaut, M. \& Pagès, J. (2008), 'Multiple factor analysis and clustering of a mixture of quantitative, categorical and frequency data', Computational Statistics \& Data Analysis 52, 3255-3268.

Belke, A. \& Spies, J. (2008), 'Enlarging the EMU to the East: What effects on trade?', Empirica 35(4), 369-389.

Bettin, G. \& Lo Turco, A. (2012), 'A cross-country view on South-North migration and trade: Dissecting the channels', Emerging Markets Finance and Trade 48, 4-29.

Blundell, R. \& Bond, S. (1998), 'Initial conditions and moment restrictions in dynamics panel data models', Journal of Econometrics 87, 115-143.

Brun, J., Carrère, C., Guillaumont, P. \& de Melo, J. (2005), 'Has distance died? Evidence from a panel gravity model', The World Bank Economic Review 19(1), 99-120.

Bun, M. \& Klaassen, F. (2002), The importance of dynamics in panel gravity models of trade, Technical report, University of Amsterdam.

Cameron, C. \& Trivedi, P. (2005), Microeconometrics: Methods and Applications, Cambridge.

Correia Leite, J. (2008), 'The determinants of colombian exports: an empirical analysis using the gravity model', Desarrollo y Sociedad 61, 165-205.

Disdier, A. \& Head, K. (2008), 'The puzzling persistence of distance effect on the bilateral trade', The Review of Economics and Statistics 90(1), 37-48.

Eaton, J. \& Kortum, S. (2002), 'Technology, geography and trade', Econometrica 70(5), 1741-1779.

Escofier, B. \& Pagès, J. (1994), 'Multiple factor analysis', Computational Statistics E Data Analysis 18, 121-140.

Evenett, S. J. \& Keller, W. (2002), 'On theories explaining the success of the gravity equation', Journal of Political Economy 110(2), 281-316.

Feenstra, R. C., Markusen, J. R. \& Rose, A. K. (2001), 'Using the gravity equation to differentiate among alternative theories of trade', Canadian Journal of Economics 34(2), 430-447. 
Gatti, R. (2004), 'Explaining corruption: Are open countries less corrupt?', Journal of International Development 16(6), 851-861.

Glick, R. \& Rose, A. K. (2002), 'Does a currency union affect trade? the timeseries evidence', European Economic Review 46(6), 1125-1151.

Head, K. \& Mayer, T. (2014), Gravity equations: Workhorse, toolkit, and cookbook, in G. Grossman \& K. Rogoff, eds, 'The Handbook of International Economics', North-Holland, Elsevier, chapter 3, pp. 131-195.

Helpman, E., Melitz, M. \& Rubinstein, Y. (2008), 'Estimating trade flows: Trading partners and trading volumes', Quarterly Journal of Economics 123(2), 441-487.

Huang, R. (2007), 'Distance and trade: Disentangling unfamiliarity effects and transport cost effects', European Economic Review 51, 161-181.

Husson, F., Josse, J., Le, S. \& Mazet, J. (2013), Multivariate Exploratory Data Analysis and Data Mining with R. R package 1.25.

Kucera, D. \& Sarna, R. (2006), 'Trade union rights, democracy, and exports: a gravity model approach', Review of International Economics 14, 859-881.

Leamer, E. \& Levinsohn, J. (1995), International trade theory: The evidence, in G. Grossman \& K. Rogoff, eds, 'The Handbook of International Economics', North-Holland, Elsevier.

Limáo, N. \& Venables, A. J. (2013), 'Infrastructure, geographical disadvantage, transport costs, and trade', World Bank Econ Rev 15(3), 451-479.

Mejia, J. F. (2011), Export Diversification and Economic Growth: An Analysis of Colombia's Export Competitiveness in the European Union's Market, SpringerVerlag, Berlin.

Micco, A., Stein, E., Ordoñez, G., Midelfart, K. H. \& Viaene, J. M. (2003), 'The currency union effect on trade: Early evidence from EMU', Economic Policy 18(37), 317-356.

Pagès, J. (2004), 'Analyse factorielle de donnees mixtes', Revue Statistique Appliquee 4, 93-111.

Rose, A. K. (2000), 'One money, one market: Estimating the effect of common currencies on trade', Economic Policy 15(30), 7-46.

Rose, A. K. (2004), 'Do we really know that the WTO increases trade?', American Economic Review 94(1), 98-114.

Silva, S. \& Tenreyro, S. (2006), 'The log of gravity', The Review of Economics and Statistics 88(4), 641-658.

Soloaga, I. \& Winters, L. A. (2001), 'Regionalism in the nineties: What effect on trade?', North American Journal of Economics and Finance 12(1), 1-29.

Stack, M. (2009), 'Regional integration and trade: Controlling for varying degrees of heterogeneity in the gravity model', The World Economy 32(5), 772789 . 
StataCorp (2011), Stata Statistical Software: Release 12, College Station, TX: StataCorp LP.

Subramanian, A. \& Wei, S. (2007), 'The WTO promotes trade, strongly but unevenly', Journal of International Economics 72(1), 151-175.

Swamy, A., Knack, S., Lee, Y. \& Azfar, O. (2001), 'Gender and corruption', Journal of Development Economics 64, 25-55.

Uzagalieva, A., Kočenda, E. \& Menezes, A. (2012), 'Technological innovation in new EU markets', Emerging Markets Finance and Trade 48, 48-65.

Walkenhorst, P. (2004), 'Economic transition and the sectoral patterns of foreign direct investment', Emerging Markets Finance and Trade 40, 5-26.

Yu, M. (2010), 'Trade, democracy, and the gravity equation', Journal of Development Economics 91(2), 289-300.

\section{Appendix A}


Table A.1: Data sources and calculations

\begin{tabular}{|c|c|c|}
\hline Variable & Definition & Source \\
\hline Exports & $\begin{array}{l}\text { Value of exports to trade partner } \\
\text { in US\$ }\end{array}$ & $\begin{array}{l}\text { IMF's Direction of Trade Statis- } \\
\text { tics }\end{array}$ \\
\hline GDP & Exporter country's GDP in US\$ & $\begin{array}{lrr}\text { United } & \text { Nations } & \text { National Ac- } \\
\text { counts, } & \text { Main } & \text { Aggregates } \\
\text { Database } & & \end{array}$ \\
\hline GDPPartner & Importer country's GDP in US\$ & $\begin{array}{lrr}\text { United } & \text { Nations } & \text { National Ac- } \\
\text { counts, } & \text { Main } & \text { Aggregates } \\
\text { Database } & & \end{array}$ \\
\hline Political Difference & $\begin{array}{l}\text { Absolute value of the difference } \\
\text { between Democracy Index in } \\
\text { both countries }\end{array}$ & $\begin{array}{l}\text { Democracy Index measured by } \\
\text { Polity } 2 \\
\text { variable from the Polity IV data } \\
\text { set }\end{array}$ \\
\hline Distance & $\begin{array}{l}\text { Great-circle distance between } \\
\text { the trade partners } \\
\text { measured in kilometres }\end{array}$ & $\begin{array}{l}\text { CIA World Factbook (latitudes } \\
\text { and longitudes, capital cities). } \\
\text { US Federal Communications } \\
\text { Commission Website, Converter }\end{array}$ \\
\hline Real Exchange Rate & Bilateral real exchange rate & $\begin{array}{l}\text { IMF's International Financial } \\
\text { Statistics Database (nominal ex- } \\
\text { change rates, producer price in- } \\
\text { dexes) }\end{array}$ \\
\hline Border & $\begin{array}{l}\text { Binary dummy variable, unity if } \\
\text { the country pair shares a land } \\
\text { border }\end{array}$ & CIA World Factbook \\
\hline Island & $\begin{array}{l}\text { Dummy variable, unity if the } \\
\text { partner country is an island }\end{array}$ & CIA World Factbook \\
\hline Common Language & $\begin{array}{l}\text { Dummy variable, takes the } \\
\text { value of one if both countries } \\
\text { share a common language }\end{array}$ & CIA World Factbook \\
\hline
\end{tabular}

Source: Author's calculations.

Dummy variable, unity if the CIA World Factbook

alue of one if both countries

Source: Author's calculations. 
Table A.3: South America: Countries by Economic Distance Index

\begin{tabular}{|c|c|c|c|c|c|c|c|c|c|}
\hline \multicolumn{2}{|l|}{ ARGENTINA } & \multicolumn{2}{|l|}{ BRAZIL } & \multicolumn{2}{|l|}{ CHILE } & \multicolumn{2}{|l|}{ COLOMBIA } & \multicolumn{2}{|l|}{ ECUADOR } \\
\hline PARAGUAY & $-2,82$ & PARAGUAY & $-2,63$ & ARGENTINA & $-3,02$ & ECUADOR & $-2,21$ & COLOMBIA & $-2,68$ \\
\hline URUGUAY & $-2,80$ & ARGENTINA & $-2,49$ & BOLIVIA & $-3,02$ & VENEZUELA & $-2,07$ & PERU & $-2,39$ \\
\hline CHILE & $-2,77$ & URUGUAY & $-2,47$ & PERU & $-2,84$ & $\begin{array}{l}\text { PANAMA } \\
\text { PAM }\end{array}$ & $-1,90$ & VENEZUELA & $-1,45$ \\
\hline BOLIVIA & $-2,68$ & COLOMBIA & $-2,35$ & URUGUAY & $-1,85$ & HONDURAS & $-1,85$ & HONDURAS & $-1,45$ \\
\hline BRAZIL & $-1,72$ & PERU & $-2,29$ & PARAGUAY & $-1,81$ & EL SALVADOR & $-1,83$ & EL SALVADOR & $-1,44$ \\
\hline COLOMBIA & $-1,36$ & VENEZUELA & $-2,23$ & COLOMBIA & $-1,51$ & PERU & $-1,80$ & PANAMA & $-1,43$ \\
\hline PERU & $-1,34$ & CHILE & $-0,88$ & COSTA RICA & $-1,47$ & GUATEMALA & $-1,55$ & GUATEMALA & $-1,39$ \\
\hline ECUADOR & $-1,16$ & ECUADOR & $-0,68$ & ECUADOR & $-1,38$ & BOLIVIA & $-1,45$ & COSTA RICA & $-1,38$ \\
\hline VENEZUELA & $-1,08$ & PORTUGAL & $-0,53$ & GUATEMALA & $-1,36$ & MEXICO & $-1,43$ & BOLIVIA & $-1,38$ \\
\hline MEXICO & $-1,07$ & MEXICO & $-0,42$ & PANAMA & $-1,28$ & ARGENTINA & $-1,25$ & MEXICO & $-1,26$ \\
\hline SPAIN & $-0,53$ & UNITED STATES & $-0,28$ & VENEZUELA & $-1,25$ & COSTA RICA & $-1,24$ & CHILE & $-1,19$ \\
\hline SOUTH AFRICA & $-0,06$ & SOUTH AFRICA & $-0,28$ & MEXICO & $-1,25$ & BRAZIL & $-1,21$ & ARGENTINA & $-1,17$ \\
\hline UNITED STATES & 0,20 & CANADA & $-0,23$ & SPAIN & $-0,69$ & CHILE & $-1,17$ & SPAIN & $-0,70$ \\
\hline CANADA & 0,22 & SPAIN & $-0,18$ & BRAZIL & $-0,62$ & SPAIN & $-0,08$ & BRAZIL & $-0,29$ \\
\hline PORTUGAL & 0,32 & FRANCE & $-0,09$ & CANADA & 0,07 & CANADA & 0,40 & UNITED STATES & $-0,11$ \\
\hline ITALY & 0,33 & SWITZERLAND & $-0,05$ & PORTUGAL & 0,24 & UNITED STATES & 0,41 & CANADA & $-0,05$ \\
\hline DENMARK & 0,39 & ITALY & $-0,04$ & UNITED STATES & 0,31 & ROMANIA & 0,44 & PORTUGAL & 0,20 \\
\hline FRANCE & 0,42 & NETHERLANDS & 0,00 & DENMARK & 0,33 & TRINIDAD AND TOBAGO & 0,49 & FRANCE & 0,25 \\
\hline POLAND & 0,42 & NORWAY & 0,00 & NORWAY & 0,34 & BULGARIA & 0,58 & NORWAY & 0,36 \\
\hline SWITZERLAND & 0,45 & SWEDEN & 0,04 & SWEDEN & 0,37 & NORWAY & 0,62 & DENMARK & 0,37 \\
\hline TURKEY & 0,47 & GERMANY & 0,06 & POLAND & 0,38 & HUNGARY & 0,62 & ITALY & 0,38 \\
\hline NETHERLANDS & 0,53 & TURKEY & 0,06 & FRANCE & 0,39 & DENMARK & 0,64 & POLAND & 0,40 \\
\hline GERMANY & 0,58 & FINLAND & 0,18 & SWITZERLAND & 0,40 & POLAND & 0,65 & SWEDEN & 0,40 \\
\hline INDIA & 0,69 & EGYPT & 0,44 & BULGARIA & 0,41 & SWEDEN & 0,66 & TURKEY & 0,40 \\
\hline THAILAND & 0,89 & INDIA & 0,47 & ITALY & 0,42 & FRANCE & 0,68 & GERMANY & 0,40 \\
\hline EGYPT & 0,91 & IRAN & 0,55 & GREECE & 0,46 & PORTUGAL & 0,79 & GREECE & 0,45 \\
\hline MALAYSIA & 0,91 & SYRIA & 0,61 & NETHERLANDS & 0,46 & BELGIUM-LUXEMBOURG & 0,81 & REPUBLIC OF KOREA & 0,73 \\
\hline REPUBLIC OF KOREA & 1,00 & SAUDI ARABIA & 0,82 & GERMANY & 0,52 & SWITZERLAND & 0,90 & INDIA & 0,82 \\
\hline AUSTRALIA & 1,02 & THAILAND & 0,83 & TURKEY & 0,55 & NETHERLANDS & 0,99 & UNITED KINGDOM & 1,18 \\
\hline UNITED KINGDOM & 1,19 & UNITED ARAB EMIRATES & 0,83 & FINLAND & 0,60 & ITALY & 0,99 & MALAYSIA & 1,25 \\
\hline UNITED ARAB EMIRATES & 1,26 & REPUBLIC OF KOREA & 0,88 & INDIA & 0,74 & AUSTRIA & 1,03 & AUSTRALIA & 1,53 \\
\hline SAUDI ARABIA & 1,29 & $\begin{array}{l}\text { MALAYSIA } \\
\text { PAI }\end{array}$ & 0,90 & REPUBLIC OF KOREA & 0,92 & GREECE & 1,04 & UNITED ARAB EMIRATES & 1,56 \\
\hline INDONESIA & 1,31 & KUWAIT & 1,07 & THAILAND & 0,92 & GERMANY & 1,06 & JAPAN & 1,57 \\
\hline PHILIPPINES & 1,38 & UNITED KINGDOM & 1,15 & AUSTRALIA & 0,95 & FINLAND & 1,10 & SAUDI ARABIA & 1,63 \\
\hline \multirow{10}{*}{$\begin{array}{l}\text { JAPAN } \\
\text { HONG KONG }\end{array}$} & 1,54 & HONG KONG & 1,50 & MALAYSIA & 0,96 & IRELAND & 1,77 & PHILIPPINES & 1,72 \\
\hline & 1,68 & AUSTRALIA & 1,67 & IRELAND & 1,10 & UNITED KINGDOM & 2,01 & HONG KONG & 1,74 \\
\hline & & INDONESIA & 1,96 & UNITED KINGDOM & 1,21 & CYPRUS & 2,34 & SINGAPORE & 2,45 \\
\hline & & JAPAN & 2,03 & UNITED ARAB EMIRATES & 1,26 & & & & \\
\hline & & PHILIPPINES & 2,09 & SAUDI ARABIA & 1,27 & & & & \\
\hline & & & & JAPAN & 1,41 & & & & \\
\hline & & & & INDONESIA & 1,42 & & & & \\
\hline & & & & PHILIPPINES & 1,45 & & & & \\
\hline & & & & HONG KONG & 1,61 & & & & \\
\hline & & & & SINGAPORE & 1,88 & & & & \\
\hline
\end{tabular}

Source: Author's estimations. 
Table A.4: Central America: Countries by Economic Distance Index

\begin{tabular}{|c|c|c|c|c|c|c|c|c|c|}
\hline \multicolumn{2}{|c|}{ EL SALVADOR } & \multicolumn{2}{|l|}{ GUATEMALA } & \multicolumn{2}{|l|}{ HOMDURAS } & \multicolumn{2}{|c|}{ MEXICO } & \multicolumn{2}{|c|}{ PANAMA } \\
\hline HONDURAS & $-2,87$ & EL SALVADOR & $-2,78$ & EL SALVADOR & $-3,06$ & GUATEMALA & $-2,92$ & COSTA RICA & $-2,75$ \\
\hline GUATEMALA & $-2,78$ & HONDURAS & $-2,77$ & GUATEMALA & $-2,96$ & HONDURAS & $-1,86$ & COLOMBIA & $-2,70$ \\
\hline COLOMBIA & $-1,52$ & MEXICO & $-2,73$ & COLOMBIA & $-1,64$ & EL SALVADOR & $-1,85$ & HONDURAS & $-1,46$ \\
\hline MEXICO & $-1,46$ & COSTA RICA & $-1,46$ & MEXICO & $-1,58$ & COSTA RICA & $-1,66$ & EL SALVADOR & $-1,43$ \\
\hline PANAMA & $-1,37$ & COLOMBIA & $-1,42$ & COSTA RICA & $-1,47$ & COLOMBIA & $-1,66$ & GUATEMALA & $-1,43$ \\
\hline ECUADOR & $-1,34$ & ECUADOR & $-1,17$ & ECUADOR & $-1,31$ & PERU & $-1,37$ & MEXICO & $-1,32$ \\
\hline COSTA RICA & $-1,29$ & PANAMA & $-1,17$ & VENEZUELA & $-1,24$ & PANAMA & $-1,37$ & BOLIVIA & $-1,23$ \\
\hline VENEZUELA & $-1,20$ & PERU & $-1,12$ & PANAMA & $-1,21$ & ECUADOR & $-1,35$ & PERU & $-1,19$ \\
\hline BOLIVIA & $-1,12$ & VENEZUELA & $-1,11$ & CHILE & $-1,09$ & VENEZUELA & $-1,27$ & CHILE & $-1,17$ \\
\hline CHILE & $-0,97$ & CHILE & $-1,09$ & SPAIN & $-0,49$ & CHILE & $-1,23$ & ECUADOR & $-1,17$ \\
\hline SPAIN & $-0,56$ & ARGENTINA & $-0,96$ & BRAZIL & $-0,12$ & UNITED STATES & $-1,22$ & VENEZUELA & $-1,16$ \\
\hline BRAZIL & $-0,20$ & SPAIN & $-0,51$ & UNITED STATES & 0,00 & ARGENTINA & $-1,11$ & $\begin{array}{l}\text { SPAIN } \\
\text { SPLA }\end{array}$ & $-0,43$ \\
\hline UNITED STATES & $-0,18$ & BRAZIL & $-0,11$ & CANADA & 0,01 & URUGUAY & $-1,03$ & BRAZIL & $-0,08$ \\
\hline $\begin{array}{l}\text { PERU } \\
\text { PITL }\end{array}$ & $-0,13$ & UNITED STATES & $-0,06$ & TRINIDAD AND TOBAGO & 0,25 & SPAIN & $-0,62$ & CANADA & 0,07 \\
\hline CANADA & $-0,11$ & CANADA & $-0,05$ & DENMARK & 0,36 & CANADA & $-0,20$ & UNITED STATES & 0,09 \\
\hline FRANCE & 0,24 & NORWAY & 0,25 & SWEDEN & 0,37 & BRAZIL & $-0,12$ & DENMARK & 0,28 \\
\hline NORWAY & 0,28 & SWEDEN & 0,28 & PORTUGAL & 0,42 & SWEDEN & 0,26 & SWEDEN & 0,29 \\
\hline PORTUGAL & $\begin{array}{l}0,20 \\
0,29\end{array}$ & POLAND & 0,38 & FRANCE & 0,44 & REPUBLIC OF KOREA & 0,30 & POLAND & 0,40 \\
\hline NETHERLANDS & 0,37 & PORTUGAL & 0,38 & REPUBLIC OF KOREA & 0,48 & HUNGARY & 0,31 & PORTUGAL & 0,43 \\
\hline SWITZERLAND & 0,40 & FRANCE & 0,40 & SWITZERLAND & 0,55 & DENMARK & 0,32 & FRANCE & 0,55 \\
\hline GERMANY & 0,42 & REPUBLIC OF KOREA & 0,43 & NETHERLANDS & 0,58 & POLAND & 0,34 & SWITZERLAND & 0,56 \\
\hline SWEDEN & 0,42 & SWITZERLAND & 0,47 & ITALY & 0,61 & FRANCE & 0,38 & NETHERLANDS & 0,64 \\
\hline $\begin{array}{l}\text { ITALY } \\
\text { ITV }\end{array}$ & 0,45 & NETHERLANDS & 0,50 & FINLAND & 0,64 & PORTUGAL & 0,38 & ITALY & 0,64 \\
\hline FINLAND & 0,45 & ITALY & 0,54 & GERMANY & 0,64 & SWITZERLAND & 0,48 & REPUBLIC OF KOREA & 0,68 \\
\hline REPUBLIC OF KOREA & 0,49 & FINLAND & 0,56 & INDIA & 0,77 & NETHERLANDS & 0,49 & GERMANY & 0,71 \\
\hline GREECE & 0,55 & GERMANY & 0,56 & THAILAND & 1,05 & TURKEY & 0,54 & INDIA & 0,75 \\
\hline SOUTH AFRICA & 0,64 & INDIA & 0,68 & IRELAND & 1,13 & FINLAND & 0,54 & THAILAND & 1,16 \\
\hline INDIA & 0,79 & THAILAND & 0,94 & JAPAN & 1,15 & ITALY & 0,56 & HONG KONG & 1,41 \\
\hline THAILAND & 1,22 & MALAYSIA & 1,17 & UNITED KINGDOM & 1,29 & GERMANY & 0,56 & $\begin{array}{l}\text { JAPAN } \\
\text { INA }\end{array}$ & $\begin{array}{l}1,41 \\
1,47\end{array}$ \\
\hline JAPAN & 1,57 & JAPAN & 1,18 & AUSTRALIA & 1,49 & INDIA & 0,59 & IRELAND & 1,56 \\
\hline UNITED KINGDOM & 1,62 & IRELAND & 1,23 & HONG KONG & 1,91 & THAILAND & 0,98 & UNITED KINGDOM & 1,80 \\
\hline AUSTRALIA & 1,68 & UNITED KINGDOM & 1,39 & SAUDI ARABIA & 2,04 & MALAYSIA & 1,15 & AUSTRALIA & 1,87 \\
\hline & 2,36 & HONG KONG & 1,58 & & & JAPAN & 1,38 & INDONESIA & 2,14 \\
\hline \multirow[t]{6}{*}{ SINGAPORE } & 2,85 & UNITED ARAB EMIRATES & 1,61 & & & IRELAND & 1,49 & & \\
\hline & $2,0 J$ & $\begin{array}{l}\text { SAUDI ARABIA } \\
\text { SIIKAILS }\end{array}$ & $\begin{array}{l}1,01 \\
1,68\end{array}$ & & & UNITED KINGDOM & $\begin{array}{l}1,49 \\
1,66\end{array}$ & & \\
\hline & & SINGAPORE & 2,32 & & & HONG KONG & 1,68 & & \\
\hline & & & & & & AUSTRALIA & 1,81 & & \\
\hline & & & & & & SAUDI ARABIA & 1,94 & & \\
\hline & & & & & & SINGAPORE & 2,66 & & \\
\hline
\end{tabular}

Source: Author's estimations. 
Table A.5: Principal Components Analysis: An Economic Distance Index

\begin{tabular}{|c|c|c|c|c|c|c|c|c|c|c|}
\hline Country & & & & & & & & & & \\
\hline Variable & Argentine & Brazil & Chile & Colombia & Ecuador & EL Salvador & Guatemala & Honduras & Mexico & Panam \\
\hline Distance & 0,5726 & 0,6547 & 0,5890 & 0,5135 & 0,5802 & 0,5419 & 0,5524 & 0,5443 & 0,5879 & 0,5465 \\
\hline Real Exchange Rate & 0,1540 & 0,0872 & 0,1300 & 0,3577 & 0,1666 & 0,2078 & 0,1848 & 0,1908 & 0,1815 & 0,2731 \\
\hline Political Difference & 0,2318 & 0,2634 & 0,1990 & 0,4000 & 0,3207 & 0,3928 & 0,3376 & 0,3593 & 0,3699 & 0,0808 \\
\hline Border & $-0,4976$ & $-0,5892$ & $-0,4149$ & $-0,3257$ & $-0,3178$ & $-0,3589$ & $-0,4215$ & $-0,4061$ & $-0,2475$ & $-0,368 \mathrm{~s}$ \\
\hline Island & 0,2612 & 0,3804 & 0,3066 & 0,2671 & 0,3433 & 0,3372 & 0,2734 & 0,2422 & 0,3514 & 0,3963 \\
\hline Common Language & $-0,5280$ & $-0,0507$ & $-0,5748$ & $-0,5205$ & $-0,5603$ & $-0,5161$ & $-0,5425$ & $-0,5608$ & $-0,5477$ & $-0,571 \mathrm{c}$ \\
\hline Proportion $^{a}$ & $42,28 \%$ & $31,80 \%$ & $39,79 \%$ & $45,84 \%$ & $40,07 \%$ & $41,79 \%$ & $40,98 \%$ & $39,53 \%$ & $37,36 \%$ & $38,29 \%$ \\
\hline
\end{tabular}

${ }^{a}$ Proportion of the variance explained by the first dimension.

Source: Author's estimations. 
Table A.6: Econometric Results: Dynamic Panel Data Model using PCA

\begin{tabular}{|c|c|c|c|c|c|c|c|c|c|c|}
\hline Variable & Argentine & Brazil & Chile & Colombia & Ecuador & EL Salvador & Guatemala & Honduras & Mexico & Panama \\
\hline EcDist $_{i t}$ & $\begin{array}{c}-0,8116 \\
(0,0252)\end{array}$ & $\begin{array}{c}-0,2565 \\
(0,0370)\end{array}$ & $\begin{array}{c}-0,3670 \\
(0,0148)\end{array}$ & $\begin{array}{c}-0,2588 \\
(0,0173)\end{array}$ & $\begin{array}{c}-1,5484 \\
(0,0462)\end{array}$ & $\begin{array}{c}-1,1298 \\
(0,0777)\end{array}$ & $\begin{array}{c}-0,3874 \\
(0,0254)\end{array}$ & $\begin{array}{c}-1,1159 \\
(0,1813)\end{array}$ & $\begin{array}{c}-0,3220 \\
(0,0295)\end{array}$ & $\begin{array}{c}-3,2345 \\
(0,1024)\end{array}$ \\
\hline $\ln G D P_{i t}$ & $\begin{array}{l}0,2745 \\
(0,0069)\end{array}$ & $\begin{array}{l}0,2351 \\
(0,0081)\end{array}$ & $\begin{array}{l}0,8512 \\
(0,0087)\end{array}$ & $\begin{array}{l}0,4892 \\
(0,0095)\end{array}$ & $\begin{array}{l}0,5878 \\
(0,0164)\end{array}$ & $\begin{array}{l}1,1895 \\
(0,0394)\end{array}$ & $\begin{array}{l}0,4605 \\
(0,0177)\end{array}$ & $\begin{array}{l}0,9371 \\
(0,0222)\end{array}$ & $\begin{array}{l}0,4543 \\
(0,0159)\end{array}$ & $\begin{array}{l}0,5654 \\
(0,0561)\end{array}$ \\
\hline $\ln \operatorname{Exp}_{i t-1}$ & $\begin{array}{l}0,6929 \\
(0,0104)\end{array}$ & $\begin{array}{l}0,7039 \\
(0,0113)\end{array}$ & $\begin{array}{l}0,0101 \\
(0,0015)\end{array}$ & $\begin{array}{l}0,3229 \\
(0,0076)\end{array}$ & $\begin{array}{l}0,5915 \\
(0,0017)\end{array}$ & $\begin{array}{l}0,1263 \\
(0,0051)\end{array}$ & $\begin{array}{l}0,3401 \\
(0,0074)\end{array}$ & $\begin{array}{l}0,0621 \\
(0,0057)\end{array}$ & $\begin{array}{l}0,4835 \\
(0,0142)\end{array}$ & $\begin{array}{l}0,1754 \\
(0,0089)\end{array}$ \\
\hline Constant & $\begin{array}{c}-8,2521 \\
(0,2204)\end{array}$ & $\begin{array}{c}-6,4801 \\
(0,2246)\end{array}$ & $\begin{array}{c}-24,9264 \\
(0,4435)\end{array}$ & $\begin{array}{c}-12,8217 \\
(0,4153)\end{array}$ & $\begin{array}{c}-22,5669 \\
(0,8322)\end{array}$ & $\begin{array}{l}-46,2200 \\
(2,0225)\end{array}$ & $\begin{array}{c}-12,0964 \\
(0,8355)\end{array}$ & $\begin{array}{c}-32,7187 \\
(1,1197)\end{array}$ & $\begin{array}{c}-14,1065 \\
(0,6257)\end{array}$ & $\begin{array}{c}-16,4352 \\
(2,7790)\end{array}$ \\
\hline $\begin{array}{l}\text { Long Term Economic Distance } \\
\text { Semi-elasticity }\end{array}$ & $-2,643$ & $-0,8663$ & $-0,3707$ & $-0,3823$ & $-3,7909$ & $-1,2932$ & $-0,5871$ & $-1,1898$ & $-0,6235$ & $-3,9223$ \\
\hline Long Term GDP Elasticity & 0,8939 & 0,794 & 0,8598 & 0,7225 & 1,4391 & 1,3615 & 0,6978 & 0,9991 & 0,8796 & 0,6856 \\
\hline Autocorrelation Testa & $-1.0075+$ & $-1.6787+$ & $0.2728+$ & $0.0296+$ & $1.3459+$ & $-0.4907+$ & $1.5710+$ & $1.5608+$ & $0.0419+$ & $0.7028+$ \\
\hline OIR Testb & $35.3612+$ & $38.5987+$ & $43.1190+$ & $36.0049+$ & $35.4587+$ & $31.3089+$ & $35.6524+$ & $30.9464+$ & $38.4743+$ & $29.1817+$ \\
\hline PUR Testc & $-11.4508-$ & $-1.4259-$ & $-12.2991-$ & $-9.9089-$ & $-5.9416-$ & $-14.482-$ & $-4.4724-$ & $-3.1642-$ & $-3.6359-$ & $-8.2050-$ \\
\hline
\end{tabular}

Source: Authors' estimations. Standard deviations in parentheses. All variables are statistically significant at $5 \%$.

a Arellano-Bond autocorrelation test. Null hypothesis: No autocorrelation of order 2.

b Sargent test of Over Identification Restrictions. Null hypothesis: Overidentifying restrictions are valid.

c Harris and Tzavalis (1999) Panel Unit Root test applied to lnExpit. Null hypothesis: panel unit root.

+ No rejection of the null hypothesis.

- Rejection of the null hypothesis. 
Table A.7: Econometric Results: Static Panel Data Models using FAMD (South America)

\begin{tabular}{|c|c|c|c|c|c|}
\hline \multicolumn{6}{|c|}{ Argentina } \\
\hline Variable & Pooled OLS & FGLS AR(1) & Prais-Winsten & Random Effect & Instrumental Variable \\
\hline EcDistit & $\begin{array}{c}-0,6908 \\
(0,1156)\end{array}$ & $\begin{array}{c}-0,7053 \\
(0,1232)\end{array}$ & $\begin{array}{c}-0,6817 \\
(0,1682)\end{array}$ & $\begin{array}{c}-0,6916 \\
(0,1103)\end{array}$ & $\begin{array}{c}-0,6246 \\
(0,0901)\end{array}$ \\
\hline $\ln G D P$ it & $\begin{array}{l}0,6361 \\
(0,1044)\end{array}$ & $\begin{array}{l}0,6443 \\
(0,1099)\end{array}$ & $\begin{array}{l}0,5752 \\
(0,1292)\end{array}$ & $\begin{array}{l}0,6895 \\
(0,1103)\end{array}$ & $\begin{array}{l}0,6033 \\
(0,0861)\end{array}$ \\
\hline Constant & $\begin{array}{c}-13,7579 \\
(5,5745)\end{array}$ & $\begin{array}{c}-14,2361 \\
(5,8810)\end{array}$ & $\begin{array}{c}-10,7111 \\
(6,9561)\end{array}$ & $\begin{array}{c}-16,5664 \\
(5,8892)\end{array}$ & $\begin{array}{c}-11,9290 \\
(4,5269)\end{array}$ \\
\hline \multicolumn{6}{|c|}{ Brazil } \\
\hline EcDistit & $\begin{array}{c}-0,4506 \\
(0,0790)\end{array}$ & $\begin{array}{c}-0,3702 \\
(0,0801)\end{array}$ & $\begin{array}{c}-0,4072 \\
(0,0392)\end{array}$ & $\begin{array}{c}-0,3843 \\
(0,0832)\end{array}$ & $\begin{array}{c}-0,3798 \\
(0,0718)\end{array}$ \\
\hline $\ln G D P$ Pit & $\begin{array}{l}0,6216 \\
(0,0487)\end{array}$ & $\begin{array}{l}0,5851 \\
(0,0285)\end{array}$ & $\begin{array}{l}0,5960 \\
(0,0277)\end{array}$ & $\begin{array}{l}0,7193 \\
(0,0213)\end{array}$ & $\begin{array}{l}0,6007 \\
(0,0209)\end{array}$ \\
\hline Constant & $\begin{array}{c}-12,8745 \\
(2,6290)\end{array}$ & $\begin{array}{c}-10,9692 \\
(1,5452)\end{array}$ & $\begin{array}{c}-11,5370 \\
(1,5016)\end{array}$ & $\begin{array}{c}-18,1247 \\
(1,1712)\end{array}$ & $\begin{array}{c}-11,7063 \\
(1,1284)\end{array}$ \\
\hline \multicolumn{6}{|c|}{ Chile } \\
\hline EcDistit & $\begin{array}{c}-0,5444 \\
(0,0754)\end{array}$ & $\begin{array}{c}-0,5441 \\
(0,0768)\end{array}$ & $\begin{array}{c}-0,5285 \\
(0,1244)\end{array}$ & $\begin{array}{c}-0,5371 \\
(0,0864)\end{array}$ & $\begin{array}{c}-0,5001 \\
(0,0818)\end{array}$ \\
\hline $\ln G D P i t$ & $\begin{array}{l}0,8196 \\
(0,0541)\end{array}$ & $\begin{array}{l}0,8300 \\
(0,0573)\end{array}$ & $\begin{array}{l}0,8359 \\
(0,0985)\end{array}$ & $\begin{array}{l}0,8625 \\
(0,0612)\end{array}$ & $\begin{array}{l}0,7690 \\
(0,0463)\end{array}$ \\
\hline Constant & $\begin{array}{c}-23,1168 \\
(2,7888)\end{array}$ & $\begin{array}{c}-23,6770 \\
(2,9607)\end{array}$ & $\begin{array}{c}-24,0371 \\
(5,1971)\end{array}$ & $\begin{array}{c}-25,3276 \\
(3,1582)\end{array}$ & $\begin{array}{c}-20,4755 \\
(2,3912)\end{array}$ \\
\hline \multicolumn{6}{|c|}{ Colombia } \\
\hline EcDistit & $\begin{array}{c}-0,8178 \\
(0,1453)\end{array}$ & $\begin{array}{c}-0,6340 \\
(0,1118)\end{array}$ & $\begin{array}{c}-0,6730 \\
(0,1108)\end{array}$ & $\begin{array}{c}-0,4655 \\
(0,0933)\end{array}$ & $\begin{array}{c}-0,4338 \\
(0,0912)\end{array}$ \\
\hline $\ln G D P$ Pit & $\begin{array}{l}0,8151 \\
(0,1386)\end{array}$ & $\begin{array}{l}0,7304 \\
(0,0970)\end{array}$ & $\begin{array}{l}0,7451 \\
(0,0849)\end{array}$ & $\begin{array}{l}0,7374 \\
(0,0979)\end{array}$ & $\begin{array}{l}0,6960 \\
(0,0468)\end{array}$ \\
\hline Constant & $\begin{array}{c}-23,7682 \\
(7,2072)\end{array}$ & $\begin{array}{c}-19,4660 \\
(5,1214)\end{array}$ & $\begin{array}{c}-20,2142 \\
(4,4427)\end{array}$ & $\begin{array}{c}-19,7699 \\
(5,0905)\end{array}$ & $\begin{array}{c}-17,6023 \\
(2,4259)\end{array}$ \\
\hline \multicolumn{6}{|c|}{ Ecuador } \\
\hline EcDistit & $\begin{array}{c}-1,4567 \\
(0,1998)\end{array}$ & $\begin{array}{c}-1,4791 \\
(0,2143)\end{array}$ & $\begin{array}{c}-1,4711 \\
(0,1988)\end{array}$ & $\begin{array}{c}-1,5113 \\
(0,2414)\end{array}$ & $\begin{array}{c}-1,4722 \\
(0,1831)\end{array}$ \\
\hline InGDPit & $\begin{array}{l}1,0115 \\
(0,1544)\end{array}$ & $\begin{array}{l}1,0459 \\
(0,1602)\end{array}$ & $\begin{array}{l}1,0553 \\
(0,1172)\end{array}$ & $\begin{array}{l}1,1327 \\
(0,1835)\end{array}$ & $\begin{array}{l}1,1590 \\
(0,1050)\end{array}$ \\
\hline Constant & $\begin{array}{c}-34,2026 \\
(7,8687)\end{array}$ & $\begin{array}{c}-36,0124 \\
(8,1881)\end{array}$ & $\begin{array}{c}-36,5238 \\
(6,0060)\end{array}$ & $\begin{array}{c}-40,2945 \\
(9,3849)\end{array}$ & $\begin{array}{c}-41,5795 \\
(5,2957)\end{array}$ \\
\hline
\end{tabular}

Source: Authors' estimations. Standard deviations in parentheses. All variables are statistically significant at $5 \%$. 
Table A.8: Econometric Results: Static Panel Data Models using PCA (Central America)

\begin{tabular}{|c|c|c|c|c|c|}
\hline \multicolumn{6}{|c|}{ El Salvador } \\
\hline Variable & Pooled OLS & FGLS AR(1) & Prais-Winsten & Random Effect & Instrumental Variable \\
\hline \multicolumn{6}{|c|}{ El Salvador } \\
\hline EcDistit & $\begin{array}{c}-1,4757 \\
(0,2900)\end{array}$ & $\begin{array}{c}-1,3707 \\
(0,2716)\end{array}$ & $\begin{array}{c}-1,3450 \\
(0,2773)\end{array}$ & $\begin{array}{c}-1,0060 \\
(0,3453)\end{array}$ & $\begin{array}{c}-1,0469 \\
(0,2231)\end{array}$ \\
\hline $\ln G D P$ it & $\begin{array}{l}0,9482 \\
(0,2408)\end{array}$ & $\begin{array}{l}0,9030 \\
(0,2204)\end{array}$ & $\begin{array}{l}0,8962 \\
(0,1671)\end{array}$ & $\begin{array}{l}1,1653 \\
(0,2214)\end{array}$ & $\begin{array}{l}1,1572 \\
(0,1247)\end{array}$ \\
\hline Constant & $\begin{array}{c}-32,3937 \\
(12,0957)\end{array}$ & $\begin{array}{c}-30,0812 \\
(11,1018)\end{array}$ & $\begin{array}{c}-29,7359 \\
(8,4513)\end{array}$ & $\begin{array}{c}-43,1715 \\
(11,2506)\end{array}$ & $\begin{array}{c}-42,7964 \\
(6,2169)\end{array}$ \\
\hline \multicolumn{6}{|c|}{ Guatemala } \\
\hline EcDistit & $\begin{array}{c}-0,8298 \\
(0,2034)\end{array}$ & $\begin{array}{c}-0,8637 \\
(0,2055)\end{array}$ & $\begin{array}{c}-0,8402 \\
(0,1775)\end{array}$ & $\begin{array}{c}-0,7572 \\
(0,1983)\end{array}$ & $\begin{array}{c}-0,7338 \\
(0,1724)\end{array}$ \\
\hline $\ln G D P$ it & $\begin{array}{l}0,5529 \\
(0,1865)\end{array}$ & $\begin{array}{l}0,6325 \\
(0,1773)\end{array}$ & $\begin{array}{l}0,6517 \\
(0,1300)\end{array}$ & $\begin{array}{l}0,7850 \\
(0,1519)\end{array}$ & $\begin{array}{l}0,6757 \\
(0,0706)\end{array}$ \\
\hline Constant & $\begin{array}{c}-11,2263 \\
(9,3654)\end{array}$ & $\begin{array}{c}-15,2449 \\
(8,9658)\end{array}$ & $\begin{array}{c}-16,2173 \\
(6,5927)\end{array}$ & $\begin{array}{c}-22,8501 \\
(7,7022)\end{array}$ & $\begin{array}{c}-17,2927 \\
(3,5573)\end{array}$ \\
\hline \multicolumn{6}{|c|}{ Honduras } \\
\hline EcDistit & $\begin{array}{c}-1,8806 \\
(0,3514)\end{array}$ & $\begin{array}{c}-2,1698 \\
(0,3944)\end{array}$ & $\begin{array}{c}-2,1394 \\
(0,2922)\end{array}$ & $\begin{array}{c}-2,5399 \\
(0,4845)\end{array}$ & $\begin{array}{c}-1,8706 \\
(0,2941)\end{array}$ \\
\hline $\ln G D P$ it & $\begin{array}{l}1,5970 \\
(0,3713)\end{array}$ & $\begin{array}{l}1,8512 \\
(0,4008)\end{array}$ & $\begin{array}{l}1,8246 \\
(0,2374)\end{array}$ & $\begin{array}{l}2,6373 \\
(0,4605)\end{array}$ & $\begin{array}{l}1,8779 \\
(0,2013)\end{array}$ \\
\hline Constant & $\begin{array}{c}-64,6342 \\
(18,5010)\end{array}$ & $\begin{array}{c}-77,5194 \\
(20,0134)\end{array}$ & $\begin{array}{c}-76,1764 \\
(11,7670)\end{array}$ & $\begin{array}{c}-120,0213 \\
(22,9292)\end{array}$ & $\begin{array}{c}-77,9149 \\
(9,9261)\end{array}$ \\
\hline \multicolumn{6}{|c|}{ Mexico } \\
\hline EcDistit & $\begin{array}{c}-0,7120 \\
(0,1732)\end{array}$ & $\begin{array}{c}-0,4963 \\
(0,0954)\end{array}$ & $\begin{array}{c}-0,6491 \\
(0,0561)\end{array}$ & $\begin{array}{c}-0,3363 \\
(0,1261)\end{array}$ & $\begin{array}{c}-0,4620 \\
(0,1001)\end{array}$ \\
\hline $\ln G D P$ it & $\begin{array}{l}0,7571 \\
(0,1378)\end{array}$ & $\begin{array}{l}0,7730 \\
(0,0693)\end{array}$ & $\begin{array}{l}0,7603 \\
(0,0427)\end{array}$ & $\begin{array}{l}0,7833 \\
(0,0735)\end{array}$ & $\begin{array}{l}0,8413 \\
(0,0358)\end{array}$ \\
\hline Constant & $\begin{array}{c}-20,8834 \\
(7,3531)\end{array}$ & $\begin{array}{c}-21,6291 \\
(3,7431)\end{array}$ & $\begin{array}{c}-20,9914 \\
(2,2897)\end{array}$ & $\begin{array}{c}-22,2817 \\
(4,0213)\end{array}$ & $\begin{array}{c}-25,4095 \\
(1,9233)\end{array}$ \\
\hline \multicolumn{6}{|c|}{ Panama } \\
\hline EcDistit & $\begin{array}{c}-1,4346 \\
(0,3389)\end{array}$ & $\begin{array}{c}-1,3522 \\
(0,3146)\end{array}$ & $\begin{array}{c}-1,3398 \\
(0,3555)\end{array}$ & $\begin{array}{c}-1,3727 \\
(0,3486)\end{array}$ & $\begin{array}{c}-1,7487 \\
(0,3459)\end{array}$ \\
\hline $\ln G D P i t$ & $\begin{array}{l}0,8857 \\
(0,2336)\end{array}$ & $\begin{array}{l}0,8262 \\
(0,2166)\end{array}$ & $\begin{array}{l}0,8260 \\
(0,2322)\end{array}$ & $\begin{array}{l}0,8537 \\
(0,2594)\end{array}$ & $\begin{array}{l}1,2556 \\
(0,1829)\end{array}$ \\
\hline Constant & $\begin{array}{c}-29,5369 \\
(11,7124)\end{array}$ & $\begin{array}{c}-26,4257 \\
(10,8741)\end{array}$ & $\begin{array}{c}-26,3461 \\
(11,7299)\end{array}$ & $\begin{array}{c}-27,9477 \\
(13,0383)\end{array}$ & $\begin{array}{c}-48,2686 \\
(9,1072)\end{array}$ \\
\hline
\end{tabular}

Source: Authors' estimations. Standard deviations in parentheses. All variables are statistically significant at $5 \%$. 
Table A.9: Econometric Results: Static Panel Data Models using PCA (South America)

\begin{tabular}{|c|c|c|c|c|c|}
\hline \multicolumn{6}{|c|}{ Argentina } \\
\hline Variable & Pooled OLS & FGLS AR(1) & Prais-Winsten & Random Effect & Instrumental Variable \\
\hline EcDistit & $\begin{array}{l}-0,6985 \\
(0,1175)\end{array}$ & $\begin{array}{l}-0,7156 \\
(0,1262)\end{array}$ & $\begin{array}{l}-0,7122 \\
(0,1707)\end{array}$ & $\begin{array}{l}-0,7142 \\
(0,0967)\end{array}$ & $\begin{array}{l}-0,6548 \\
(0,0893)\end{array}$ \\
\hline $\ln G D P$ it & $\begin{array}{c}0,6437 \\
(0,1060)\end{array}$ & $\begin{array}{c}0,6543 \\
(0,1122)\end{array}$ & $\begin{array}{c}0,5962 \\
(0,1326)\end{array}$ & $\begin{array}{c}0,6976 \\
(0,0802)\end{array}$ & $\begin{array}{c}0,6170 \\
(0,0854)\end{array}$ \\
\hline Constant & $\begin{array}{c}-14,1609 \\
(5,6568)\end{array}$ & $\begin{array}{c}-14,7601 \\
(6,0019)\end{array}$ & $\begin{array}{c}-11,8195 \\
(7,1346)\end{array}$ & $\begin{array}{c}-16,9911 \\
(4,2164)\end{array}$ & $\begin{array}{c}-12,6502 \\
(4,4889)\end{array}$ \\
\hline \multicolumn{6}{|c|}{ Brazil } \\
\hline EcDistit & $\begin{array}{l}-0,4516 \\
(0,0791)\end{array}$ & $\begin{array}{l}-0,3858 \\
(0,0813)\end{array}$ & $\begin{array}{l}-0,4144 \\
(0,0394)\end{array}$ & $\begin{array}{l}-0,4024 \\
(0,0825)\end{array}$ & $\begin{array}{l}-0,3967 \\
(0,0721)\end{array}$ \\
\hline $\ln G D P$ it & $\begin{array}{c}0,6226 \\
(0,0486)\end{array}$ & $\begin{array}{c}0,5921 \\
(0,0290)\end{array}$ & $\begin{array}{c}0,6013 \\
(0,0277)\end{array}$ & $\begin{array}{c}0,7224 \\
(0,0211)\end{array}$ & $\begin{array}{c}0,6041 \\
(0,0208)\end{array}$ \\
\hline Constant & $\begin{array}{c}-12,9297 \\
(2,6267)\end{array}$ & $\begin{array}{c}-11,3463 \\
(1,5710)\end{array}$ & $\begin{array}{c}-11,8228 \\
(1,5031)\end{array}$ & $\begin{array}{c}-18,2942 \\
(1,1608)\end{array}$ & $\begin{array}{c}-11,8904 \\
(1,1270)\end{array}$ \\
\hline \multicolumn{6}{|c|}{ Chile } \\
\hline EcDistit & $\begin{array}{l}-0,5449 \\
(0,0753)\end{array}$ & $\begin{array}{l}-0,5448 \\
(0,0767)\end{array}$ & $\begin{array}{l}-0,5308 \\
(0,1248)\end{array}$ & $\begin{array}{l}-0,5388 \\
(0,0873)\end{array}$ & $\begin{array}{l}-0,5059 \\
(0,0815)\end{array}$ \\
\hline $\ln G D P$ it & $\begin{array}{c}0,8193 \\
(0,0541)\end{array}$ & $\begin{array}{c}0,8299 \\
(0,0574)\end{array}$ & $\begin{array}{c}0,8370 \\
(0,0988)\end{array}$ & $\begin{array}{c}0,8606 \\
(0,0617)\end{array}$ & $\begin{array}{c}0,7692 \\
(0,0462)\end{array}$ \\
\hline Constant & $\begin{array}{c}-23,1008 \\
(2,7901)\end{array}$ & $\begin{array}{c}-23,6733 \\
(2,9631)\end{array}$ & $\begin{array}{c}-24,0950 \\
(5,2152)\end{array}$ & $\begin{array}{c}-25,2249 \\
(3,1828)\end{array}$ & $\begin{array}{c}-20,4854 \\
(2,3844)\end{array}$ \\
\hline \multicolumn{6}{|c|}{ Colombia } \\
\hline EcDistit & $\begin{array}{l}-0,7961 \\
(0,1437)\end{array}$ & $\begin{array}{l}-0,6662 \\
(0,1134)\end{array}$ & $\begin{array}{l}-0,6992 \\
(0,1122)\end{array}$ & $\begin{array}{l}-0,5273 \\
(0,1292)\end{array}$ & $\begin{array}{l}-0,4712 \\
(0,0933)\end{array}$ \\
\hline $\ln G D P$ it & $\begin{array}{c}0,8030 \\
(0,1385)\end{array}$ & $\begin{array}{c}0,7425 \\
(0,0989)\end{array}$ & $\begin{array}{c}0,7546 \\
(0,0850)\end{array}$ & $\begin{array}{c}0,7056 \\
(0,0963)\end{array}$ & $\begin{array}{c}0,6737 \\
(0,0455)\end{array}$ \\
\hline Constant & $\begin{array}{c}-23,1453 \\
(7,2050)\end{array}$ & $\begin{array}{c}-20,0839 \\
(5,2133)\end{array}$ & $\begin{array}{c}-20,6997 \\
(4,4457)\end{array}$ & $\begin{array}{c}-18,1363 \\
(5,0036)\end{array}$ & $\begin{array}{c}-16,4650 \\
(2,3583)\end{array}$ \\
\hline \multicolumn{6}{|c|}{ Ecuador } \\
\hline EcDistit & $\begin{array}{l}-1,4102 \\
(0.2023)\end{array}$ & $\begin{array}{l}-1,4515 \\
(0,2225)\end{array}$ & $\begin{array}{l}-1,4605 \\
(0,1849)\end{array}$ & $\begin{array}{l}-1,4678 \\
(0,2353)\end{array}$ & $\begin{array}{l}-1,4353 \\
(0,1857)\end{array}$ \\
\hline $\ln G D P i t$ & $\begin{array}{c}1,0230 \\
(0,1682)\end{array}$ & $\begin{array}{c}1,0626 \\
(0,1745)\end{array}$ & $\begin{array}{c}1,0734 \\
(0,1161)\end{array}$ & $\begin{array}{c}1,1138 \\
(0,1873)\end{array}$ & $\begin{array}{c}1,1396 \\
(0,1054)\end{array}$ \\
\hline Constant & $\begin{array}{c}-34,7811 \\
(8,5666)\end{array}$ & $\begin{array}{c}-36,8605 \\
(8,9145)\end{array}$ & $\begin{array}{c}-37,4390 \\
(5,9504)\end{array}$ & $\begin{array}{c}-39,3421 \\
(9,5826)\end{array}$ & $\begin{array}{c}-40,6090 \\
(5,3152)\end{array}$ \\
\hline
\end{tabular}

Source: Authors' estimations. Standard deviations in parentheses. All variables are statistically significant at $5 \%$. 
Table A.10: Econometric Results: Static Panel Data Models using PCA (Central America)

\begin{tabular}{|c|c|c|c|c|c|}
\hline \multicolumn{6}{|c|}{ El Salvador } \\
\hline Variable & Pooled OLS & FGLS AR(1) & Prais-Winsten & Random Effect & Instrumental Variable \\
\hline EcDistit & $\begin{array}{r}-1,4410 \\
(0,2802)\end{array}$ & $\begin{array}{l}-1,3706 \\
(0,2638)\end{array}$ & $\begin{array}{l}-1,3459 \\
(0,3050)\end{array}$ & $\begin{array}{l}-1,1511 \\
(0,3394)\end{array}$ & $\begin{array}{l}-1,1235 \\
(0,2259)\end{array}$ \\
\hline $\ln G D P$ it & $\begin{array}{c}0,9682 \\
(0,2538)\end{array}$ & $\begin{array}{c}0,9363 \\
(0,2312)\end{array}$ & $\begin{array}{c}0,9309 \\
(0,1874)\end{array}$ & $\begin{array}{c}1,2206 \\
(0,2240)\end{array}$ & $\begin{array}{c}1,2038 \\
(0,1260)\end{array}$ \\
\hline Constant & $\begin{array}{c}-33,3871 \\
(12,7344)\end{array}$ & $\begin{array}{c}-31,7367 \\
(11,6302)\end{array}$ & $\begin{array}{c}-31,4544 \\
(9,4661)\end{array}$ & $\begin{array}{c}-45,9148 \\
(11,3694)\end{array}$ & $\begin{array}{c}-45,1051 \\
(6,2786)\end{array}$ \\
\hline \multicolumn{6}{|c|}{ Guatemala } \\
\hline EcDistit & $\begin{array}{l}-0,8235 \\
(0,2025)\end{array}$ & $\begin{array}{l}-0,8665 \\
(0,2052)\end{array}$ & $\begin{array}{l}-0,8547 \\
(0,1847)\end{array}$ & $\begin{array}{l}-0,7272 \\
(0,2119)\end{array}$ & $\begin{array}{l}-0,7630 \\
(0,1714)\end{array}$ \\
\hline $\ln G D P i t$ & $\begin{array}{c}0,5514 \\
(0,1866)\end{array}$ & $\begin{array}{c}0,6460 \\
(0,1773)\end{array}$ & $\begin{array}{c}0,6730 \\
(0,1329)\end{array}$ & $\begin{array}{c}0,7863 \\
(0,1495)\end{array}$ & $\begin{array}{c}0,6644 \\
(0,0699)\end{array}$ \\
\hline Constant & $\begin{array}{c}-11,1513 \\
(9,3725)\end{array}$ & $\begin{array}{c}-15,9459 \\
(8,9702)\end{array}$ & $\begin{array}{c}-17,3147 \\
(6,7437)\end{array}$ & $\begin{array}{c}-22,9154 \\
(7,5850)\end{array}$ & $\begin{array}{c}-16,7167 \\
(3,5219)\end{array}$ \\
\hline \multicolumn{6}{|c|}{ Honduras } \\
\hline EcDistit & $\begin{array}{l}-1,8609 \\
(0,3491)\end{array}$ & $\begin{array}{l}-2,1071 \\
(0,3896)\end{array}$ & $\begin{array}{l}-2,0854 \\
(0,2925)\end{array}$ & $\begin{array}{l}-2,4194 \\
(0,4539)\end{array}$ & $\begin{array}{l}-1,8213 \\
(0,2917)\end{array}$ \\
\hline $\ln G D P$ it & $\begin{array}{c}1,5852 \\
(0,3677)\end{array}$ & $\begin{array}{c}1,8233 \\
(0,3942)\end{array}$ & $\begin{array}{c}1,8006 \\
(0,2378)\end{array}$ & $\begin{array}{c}2,5851 \\
(0,4474)\end{array}$ & $\begin{array}{c}1,8348 \\
(0,1993)\end{array}$ \\
\hline Constant & $\begin{array}{c}-64,0538 \\
(18,3233)\end{array}$ & $\begin{array}{c}-76,1723 \\
(19,6914)\end{array}$ & $\begin{array}{c}-75,0172 \\
(11,7924)\end{array}$ & $\begin{array}{c}-113,1776 \\
(22,2994)\end{array}$ & $\begin{array}{c}-75,7803 \\
(9,8279)\end{array}$ \\
\hline \multicolumn{6}{|c|}{ Mexico } \\
\hline EcDistit & $\begin{array}{l}-0,7123 \\
(0,1757)\end{array}$ & $\begin{array}{l}-0,5347 \\
(0,1108)\end{array}$ & $\begin{array}{c}-0,6669 \\
(0,060)\end{array}$ & $\begin{array}{l}-0,4457 \\
(0,1276)\end{array}$ & $\begin{array}{l}-0,4854 \\
(0,1032)\end{array}$ \\
\hline $\ln G D P$ it & $\begin{array}{c}0,7659 \\
(0,1402)\end{array}$ & $\begin{array}{c}0,8090 \\
(0,0735)\end{array}$ & $\begin{array}{c}0,7901 \\
(0,0444)\end{array}$ & $\begin{array}{c}0,8077 \\
(0,0766)\end{array}$ & $\begin{array}{c}0,8416 \\
(0,0358)\end{array}$ \\
\hline Constant & $\begin{array}{c}-21,3567 \\
(7,4856)\end{array}$ & $\begin{array}{c}-23,5808 \\
(3,9757)\end{array}$ & $\begin{array}{c}-22,6035 \\
(2,3869)\end{array}$ & $\begin{array}{c}-23,5841 \\
(4,1809)\end{array}$ & $\begin{array}{c}-25,4120 \\
(1,9230)\end{array}$ \\
\hline \multicolumn{6}{|c|}{ Panama } \\
\hline EcDistit & $\begin{array}{l}-1,4118 \\
(0,3358)\end{array}$ & $\begin{array}{l}-1,3265 \\
(0,3092)\end{array}$ & $\begin{array}{l}-1,3135 \\
(0,3525)\end{array}$ & $\begin{array}{l}-1,2799 \\
(0,3330)\end{array}$ & $\begin{array}{l}-1,7237 \\
(0,3371)\end{array}$ \\
\hline $\ln G D P i t$ & $\begin{array}{c}0,8664 \\
(0,2313)\end{array}$ & $\begin{array}{c}0,8046 \\
(0,2134)\end{array}$ & $\begin{array}{c}0,8034 \\
(0,2306)\end{array}$ & $\begin{array}{c}0,7836 \\
(0,2476)\end{array}$ & $\begin{array}{c}1,1869 \\
(0,1769)\end{array}$ \\
\hline Constant & $\begin{array}{c}-28,5814 \\
(11,6004)\end{array}$ & $\begin{array}{c}-25,3561 \\
(10,7121)\end{array}$ & $\begin{array}{c}-25,2262 \\
(11,6443)\end{array}$ & $\begin{array}{c}-24,4737 \\
(12,4592)\end{array}$ & $\begin{array}{c}-44,8640 \\
(8,8099)\end{array}$ \\
\hline
\end{tabular}

Source: Authors' estimations. Standard deviations in parentheses. All variables are statistically significant at $5 \%$. 